\title{
EFFECT OF GAMMA IRRADIATION ON MECHANICAL AND THERMAL PROPERTIES OF FISH GELATIN FILM ISOLATED FROM Lates calcarifer SCALES
}

\author{
Dian Pribadi Perkasa*, Erizal, Darmawan, and Akhmad Rasyid \\ Centre for the Application of Isotopes and Radiation Technology, BATAN \\ Jl. Lebak Bulus Raya No.49, Pasar Jumat, Jakarta 12070
}

Received January 14, 2013; Accepted March 14, 2013

\begin{abstract}
The objective of this research was to investigate the effect of gamma irradiation on mechanical and thermal properties of fish gelatin films prepared from scales of Lates calcarifer. The films were irradiated by gamma rays at varied doses (0-50 kGy). The mechanical and thermal properties of irradiated gelatin films were measured by using colorimeter, Universal Testing Machine, Differential Scanning Calorimetry (DSC), and Fourier Transform Infrared (FTIR) spectrophotometer. The results showed that increasing of irradiation dose up to $50 \mathrm{kGy}$, the color of irradiated film did not change significantly $(p<0.05)$. The tensile strength of irradiated film was increased with no differences among dose variation but there was no change on elongation at break value $(p<0.05)$. The DSC spectra of irradiated gelatin films showed that irradiation did not affect melting temperature (Tm). In contrast, the glass transition temperature ( $\mathrm{Tg}$ ) of irradiated film has slight tendency to increase with increasing of radiation doses. In general, the FTIR spectra confirmed that gamma irradiation up to $50 \mathrm{kGy}$ affected the mechanical properties of gelatin films.
\end{abstract}

Keywords: gamma irradiation; fish gelatin film; mechanical property; thermal property; Lates calcarifer

\section{ABSTRAK}

Penelitian ini bertujuan menginvestigasi efek radiasi gamma terhadap sifat mekanik dan termal film gelatin ikan yang dipreparasi dari sisik kakap putih (Lates calcarifer). Film gelatin diiradiasi pada variasi dosis (0-50 kGy) menggunakan sinar gamma. Sifat mekanik dan termal film iradiasi diukur menggunakan kolorimeter, Universal Testing Machine, Differential Scanning Calorimetry (DSC), dan spektrofotometer inframerah (FTIR). Hasil menunjukkan bahwa dengan meningkatnya dosis radiasi hingga $50 \mathrm{kGy}$ tidak menyebabkan perubahan warna film secara signifikan $(p<0,05)$. Tegangan putus film iradiasi meningkat tanpa perbedaan di antara variasi dosis, sebaliknya, tidak terjadi perubahan perpanjangan putus film gelatin $(p<0,05)$. Spektra DSC film gelatin iradiasi menunjukkan bahwa iradiasi tidak memengaruhi Tm (melting temperature) film gelatin. Sebaliknya, Tg (glass transition temperature) film gelatin iradiasi cenderung meningkat dengan meningkatnya dosis iradiasi. Spektra FTIR mengkonfirmasi bahwa iradiasi sinar gamma pada dosis hingga $50 \mathrm{kGy}$ memengaruhi sifat mekanik film gelatin secara umum.

Kata Kunci: iradiasi gamma; film gelatin ikan; sifat mekanik; sifat termal; Lates calcarifer

\section{INTRODUCTION}

Gelatin film has been the focus of many researches for many years since it is a biodegradable and environmental friendly polymer [1]. In term of biomaterial applications, gelatin possesses attractive properties as it is a partially crystalline polymer and has a relatively low melting point [2-3]. Gelatin has been used as a base material in wide range application because its biosafety has been proved through its long clinical usage as surgical biomaterial [4], wound dressings [5-6], and in drugs delivery system [7-8].
Most research on gelatin film has focused on gelatin derived from mammalian sources such as bovine and porcine. Recently, there has been more interest in using fish as alternative sources of gelatin, due to religious considerations or fear of bovine spongiform encephalopathy [10]. Several studies on fish gelatin have been conducted by using gelatin from bigeye snapper and stripe red snapper [11-13], Baltic code [14-15], tilapia [16], and tuna [17]. But for application in biomaterial, fish-sourced gelatin is not preferred because it has lower mechanical properties than mammalian-sourced [18]. Therefore, fish gelatin modification is being developed gradually.

* Corresponding author. Tel/Fax : +62-21-7690709/7691607

Email address : dpribadi@batan.go.id 
Gamma irradiation is one of noble tools to improve mechanical properties of gelatin film. By means of radiation, the hydroxyl and superoxide anion radicals are generated from radiolysis of water molecules in medium which can modify the molecular properties of protein films by cross linking reaction [19]. Gamma irradiation provides advantages over other physical and chemical treatment for biomedical application as it has high penetration in medium, do not increase the medium temperature, and do not leave chemical residue [20]. Gamma irradiation is also commonly involved in sterilization of gelatin film and in functionalize gelatin molecule through grafting [21-22].

Several studies about effect of gamma radiation to mechanical properties of gelatin has been published [23-25], but most were concerned with the secondary structure of gelatin molecules in solution or gel state and little is known about film state. Indeed, irradiation of gelatin in film state is sometimes unavoidable such as sterilization of gelatin-based scaffold and grafting of gelatin-based film [26]. So that it is important to study the effect of gamma irradiation to properties of gelatin film in order to figure out the change on structure of gelatin molecule in irradiated film.

Baramundi (Lates calcarifer) is one of the commercially important fish species in Indonesia. In local markets, the fish was processed to obtain its meat and scales were dumped without utilization causing environmental pollution and resources waste. Lates calcarifer scale was known constituted significant amount of collagen as source of gelatin extraction. For making effective use of lates calcarifer scale as a gelatin resource, it is necessary to study the characteristic of its properties. So, we isolated gelatin from Lates calcarifer scales and then prepared film from it by casting at room temperature overnight. The objective of our research was to investigate the effect of gamma irradiation on mechanical and thermal properties of fish gelatin films prepared from scales of Lates calcarifer.

\section{EXPERIMENTAL SECTION}

\section{Materials}

Scales of Lates calcarifer was purchased from local market. Distilled water was used for gelatin extraction. All the other reagents were of analytical grade and used without further purification. Distilled water was used for isolation of gelatin.

\section{Instrumentation}

Gelatin was extracted from Lates calcarifer scales using autoclave, Rayva. The chemical changes of fish gelatin films were analyzed using Fourier Transform
Infrared (FTIR) IR-Prestige-21 spectrometer model 800 series, Shimadzu. Thermal properties of films were determined using DSC-60, Shimadzu. Tensile strength and elongation at break of films were measured using Universal Testing Machine Strograph-R1, Shimadzu. Color differences of irradiated films were measured using Chroma Meter CR-200b, Minolta.

\section{Procedure}

\section{Preparation of irradiated gelatin films}

Fish gelatin was isolated from scales of Lates calcarifer using distilled water at $121^{\circ} \mathrm{C}$ and pressure $1-1.5 \mathrm{~atm}$ for $20 \mathrm{~min}$. After the process, the prepared gelatin solution was separated from remaining scales and then dried at room temperature for $48 \mathrm{~h}$. Fish gelatin films were prepared by dissolving dried gelatin in distilled water with concentration of $10 \%(\mathrm{w} / \mathrm{v})$ and homogenized while stirring at $200 \mathrm{rpm}$ for $1 \mathrm{~h}$ at room temperature. The gelatin solution was poured into polypropylene mould $\left(13 \times 8 \times 0.1 \mathrm{~cm}^{3}\right)$, and casting at room temperature overnight. The gelatin films were then packaged and sealed in double polypropylene (PP) plastic and irradiated by gamma rays of $\mathrm{Co}^{60}$ at the doses from $10 \mathrm{kGy}$ up to $50 \mathrm{kGy}$.

\section{Color and mechanical test}

Colors changes of irradiated gelatin films were measured using a colorimeter (Chroma Meter CR200b, Minolta). The gelatin film was placed on a white plate and the CIE 1976 color scale was used to measure relative color change: $L=0$ (black) to $L=100$ (white); $a=-80$ (greenness) to $a=100$ (redness); and $b=-80$ (blueness) to $b=70$ (yellowness).

Mechanical properties of irradiated films such as tensile strength and elongation at break were measured using Universal Testing Machine (StrographR1, Shimadzu). Irradiated films were moulded using dumbbell ASTM-0-1822-L for the preparation of the standard size measurement. The crosshead speed was set at $25 \mathrm{~mm} / \mathrm{min}$. The resultant data was showed at the recorder. The elongation at break was defined by Eq. 1:

Elongation at break $=L_{1} / L_{0} \times 100 \%$

which $L_{o}$ is the original length and $L_{1}$ is the final length.

The tensile strength was defined by Eq. 2:

Tensile strength $=F / A$

where $F$ is the amount force of exerted while stretching a sample until the samples fails $(\mathrm{kg})$, and $A$ is the area of the samples $\left(\mathrm{cm}^{-2}\right)$.

Gel fraction of gelatin film was measured by immersing the film in a water bath for $24 \mathrm{~h}$ at room temperature. The swollen gelatin gel was then placed in a $60{ }^{\circ} \mathrm{C}$ oven for 2 days to completely dry the samples. The gel fraction was defined by Eq. 3: 


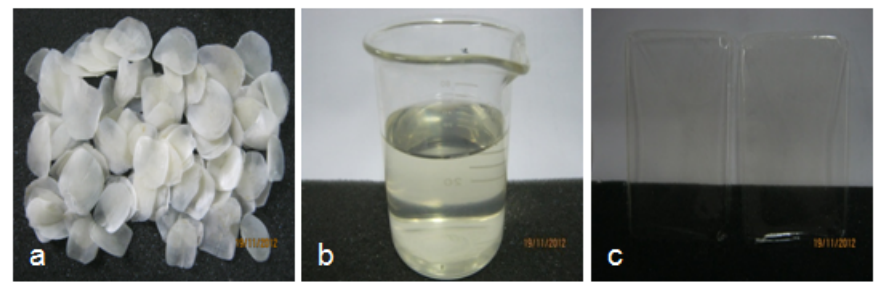

Fig 1. Raw material for extraction and gelatin product: (a) scales of Lates calcarifer, (b) gelatin solution, and (c) gelatin films

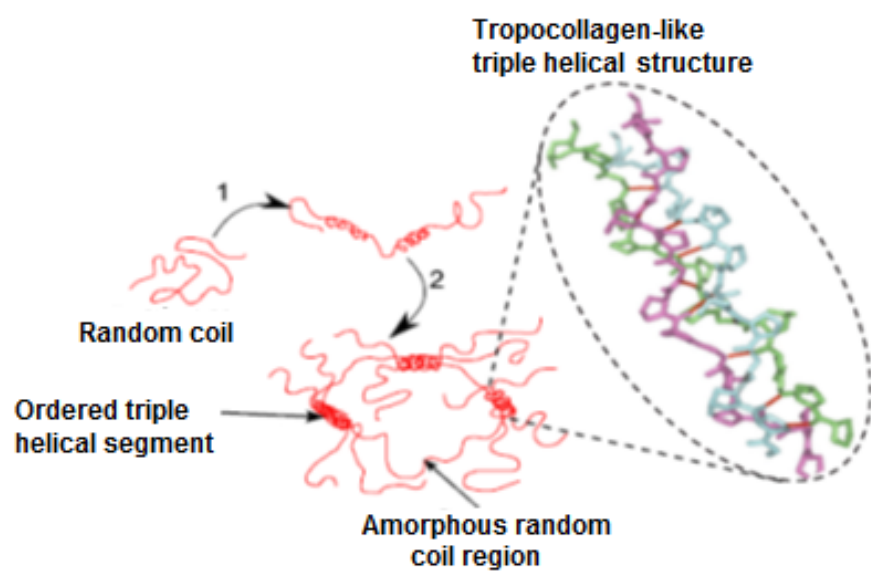

Fig 2. Schematic representation of the partial renaturation of gelatin by physical cross links during film formation

Gel fraction $=\left(\mathrm{W}_{\mathrm{d}} / \mathrm{W}_{\mathrm{i}}\right) \times 100 \%$

which $W_{d}$ is the oven-dried temperature, and $W_{i}$ is the initial weight of the gelatin film.

\section{DSC characterization}

A thermal analysis instrument (DSC-60, Shimadzu) was used to determine the thermal properties of irradiated films. The amount of gelatin films to measure DSC spectra was $5.0 \pm 0.1 \mathrm{mg})$. Each sample was heated from $23^{\circ} \mathrm{C}$ to $200^{\circ} \mathrm{C}$ in air at a rate $10{ }^{\circ} \mathrm{C} / \mathrm{min}$.

\section{FTIR characterization}

FTIR was used to characterize the presence of specific chemical groups in the irradiated gelatin films. FT-IR spectra were obtained over the range of $4000-400 \mathrm{~cm}^{-1}$. Samples were milled and mixed with dried $\mathrm{KBr}$ powder placed in a sampling cup, 20 scans were required at $2 \mathrm{~cm}^{-1}$ resolution with subtraction of the $\mathrm{KBr}$ background. FT-IR spectra were also obtained for pure gelatin for comparison with the irradiated gelatin films.

\section{Statistical analysis}

All the statistical analysis was performed by OneWay ANOVA and least significant difference (LSD) test with significance level defined at $p<0.05$.

\section{RESULT AND DISCUSSION}

\section{Fish Gelatin Film}

As shown in Fig. 1, isolation of gelatin from Lates calcarifer scales using distilled water as solvent produced a transparent, viscous, slightly yellowish solution and exhibited mild fishy odor. Unlike mammalian gelatin, extracted gelatin was in sol phase at room temperature. Relatively lower gelling temperature of fish gelatin compared to mammalian gelatin was related to lower amounts of amino acids proline and hydroxyproline in fish gelatin molecule [27].

Gelatin film was obtained by casting from gelatin aqueous solution at room temperature, as shown in Fig. 1. Gelatin films were easy to handle and its thickness was $0.2549 \pm 0.0624 \mathrm{~mm}$. During film formation, gelatin molecule was partially renaturated as schematically shown in Fig. 2 [28].

The gelatin oligomers are strongly intertwined, forming extended physical cross links resulting from the partial reversion of polypeptide chains into ordered triple helical segments, whose structure is similar to that of tropocollagen [28]. The helical structure is obtained if only the solvent is evaporated at room temperature [29-30].

\section{The Effect Irradiation Dose on Color Gelatin Films}

In visual observation, gelatin films remain clear and transparent after irradiated at doses up to $50 \mathrm{kGy}$. Colorimetry measurement also indicated no significant $(p<0.05)$ changes on color values for gelatin films with increasing irradiation dose up to $50 \mathrm{kGy}$ as shown in Table 1.

In contrast, several reports showed that gamma irradiation treatment increases yellowness of gelatin film as showed by higher $b^{*}$ of Hunter color value [3133]. Research by Inamura et al. [33] concluded that yellowness of pigskin gelatin film was significantly increase after irradiated at 10 and $40 \mathrm{kGy}$ compared to control. Yellowness shift in the irradiated protein samples is usually due to the disruption of the ordered structure of protein molecules and also by interaction between rendered amino group $\left(-\mathrm{NH}_{2}\right)$ derived from hydrolysis process and carbonyl group in gelatin via Maillard reaction [31-32].

Lee et al. [31] stated that color change of gelatin films under radiation is general, but is not universal. In this research, color of gelatin film relatively resistant against radiation. We can assume that this condition related to intrinsic characteristic of gelatin but the underlying reason is not yet clear. 
Table 1. The dose effect of gamma irradiation on color change of gelatin films

\begin{tabular}{cccc}
\hline \multirow{2}{*}{$\begin{array}{c}\text { Irradiation dosage } \\
\text { (kGy) }\end{array}$} & $\mathrm{L}^{*}$ & $\mathrm{a}^{*}$ & $\mathrm{~b}^{*}$ \\
\cline { 2 - 4 } & $61.9 \pm 0.2^{\mathrm{a}}$ & $46.8 \pm 0.5^{\mathrm{a}}$ & $-36.7 \pm 0.9^{\mathrm{a}}$ \\
0 & $61.7 \pm 0.2^{\mathrm{a}}$ & $46.6 \pm 0.3^{\mathrm{a}}$ & $-36.2 \pm 0.5^{\mathrm{a}}$ \\
20 & $61.8 \pm 0.4^{\mathrm{a}}$ & $46.8 \pm 0.4^{\mathrm{a}}$ & $-36.5 \pm 0.9^{\mathrm{a}}$ \\
30 & $61.8 \pm 0.2^{\mathrm{a}}$ & $46.5 \pm 0.3^{\mathrm{a}}$ & $-36.2 \pm 0.5^{\mathrm{a}}$ \\
40 & $61.8 \pm 0.1^{\mathrm{a}}$ & $46.5 \pm 0.3^{\mathrm{a}}$ & $-36.1 \pm 0.5^{\mathrm{a}}$ \\
50 & $61.8 \pm 0.2^{\mathrm{a}}$ & $46.4 \pm 0.4^{\mathrm{a}}$ & $-35.9 \pm 0.6^{\mathrm{a}}$
\end{tabular}

Same letter $\left({ }^{a}\right)$ within the same column did not differ significantly $(p<0.05 ; n=10)$

Table 2. Mechanical properties of fish gelatin films irradiated at different irradiation doses.

\begin{tabular}{cccc}
\hline $\begin{array}{c}\text { Radiation dose } \\
(\mathrm{kGy})\end{array}$ & Elongation at Break $(\%)$ & $\begin{array}{c}\text { Tensile Strength } \\
\left(\mathrm{kg} / \mathrm{cm}^{2}\right)\end{array}$ & $\begin{array}{c}\text { Gel Fraction } \\
(\%)\end{array}$ \\
\hline 0 & $10 \pm 0.1^{\mathrm{a}}$ & $737.66 \pm 28.28^{\mathrm{a}}$ & $1.43 \pm 0.63^{\mathrm{a}}$ \\
10 & $10 \pm 0.1^{\mathrm{a}}$ & $805.94 \pm 56.62^{\mathrm{b}}$ & $3.80 \pm 1.26^{\mathrm{ab}}$ \\
20 & $10 \pm 0.1^{\mathrm{a}}$ & $813.84 \pm 23.94^{\mathrm{b}}$ & $5.04 \pm 1.76^{\mathrm{b}}$ \\
30 & $10 \pm 0.1^{\mathrm{a}}$ & $829.25 \pm 26.48^{\mathrm{b}}$ & $5.22 \pm 1.86^{\mathrm{b}}$ \\
40 & $10 \pm 0.1^{\mathrm{a}}$ & $831.74 \pm 40.21^{\mathrm{b}}$ & $5.75 \pm 1.12^{\mathrm{b}}$ \\
50 & $10 \pm 0.1^{\mathrm{a}}$ & $825.34 \pm 39.84^{\mathrm{b}}$ & $6.27 \pm 2.22^{\mathrm{b}}$ \\
\hline
\end{tabular}

Same letter $\left({ }^{a}\right)$ within the same column did not differ significantly $(p<0.05 ; n=5)$

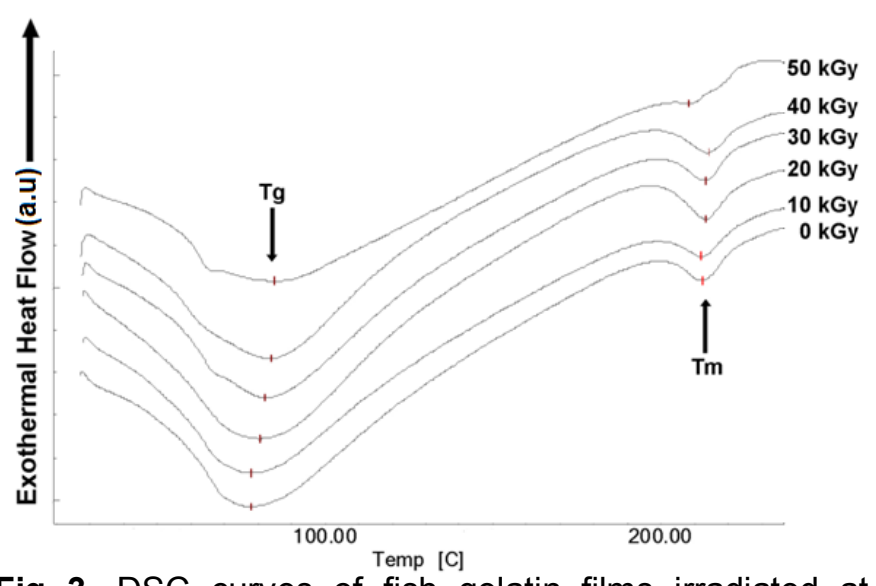

Fig 3. DSC curves of fish gelatin films irradiated at different irradiation doses

\section{Effect of Irradiation Dose on Mechanical Properties of Gelatin Films}

Effect of gamma radiation on tensile strength and elongation at break of the films at doses up to $50 \mathrm{kGy}$ are shown in Table 2. Elongation at break of gelatin films did not affected gamma irradiation $(p<0.05)$. Brittleness of gelatin film at glassy sate is well understood as gelatin molecular structure become rigid if water content is low. Interestingly, it is observed that gamma irradiation was significantly improved tensile strength of gelatin film $(p<$ 0.05 ). Tensile strength and gel fraction of irradiated gelatin film increased significantly compared to control. But, the improvement seems not correlated to increase of radiation doses as tensile strength and gel fraction was not significantly difference among irradiation dose variation.
This result was in good agreement with reports by Jo et al. [23], Lacroix et al. [34], and Ressouany et al. [35] which concluded that mechanical properties of protein films can be increased by gamma irradiation. Jo et al. [23] reported the significant increased on tensile strength of gelatin-based film after irradiated at $10 \mathrm{kGy}$. Lacroix et al. [34] indicated that an irradiation of $32 \mathrm{kGy}$ increased the puncture strength significantly in the whey protein isolate, caseinate blend or soy protein isolate film. Ressouany et al. [35] explained that gamma irradiation generates free radicals that induce chemically cross linking reaction among protein molecules at doses higher than $16 \mathrm{kGy}$.

Chemical cross links among gelatin molecules strengthen and stabilized 3D network structure of molecule gelatin formed by physical cross links during film formation [36]. Chemical cross links was proven by the increase of gel fraction of irradiated gelatin film and caused change on mechanical behavior of gelatin film such as increasing tensile strength of the film [37-39]. But not like result of Jo et al. [23], degradation of gelatin film in this research not yet occur at irradiation doses up to $50 \mathrm{kGy}$ as no significant decrease on tensile strength of gelatin film.

\section{DSC Characterization}

The DSC curve of fish gelatin films exhibited an endothermic peak as shown in Fig. 3. The endothermic peak is typical of thermo-reversible material $[2,40]$ and is considered as melting temperature $(\mathrm{Tg})$. Endothermic peaks of collagenous material are generally associated with the helix-coil transition of collagen, the rupture of hydrogen bonds and a 
Table 3. Glass transition temperature $(\mathrm{Tg})$ and melting temperature $(\mathrm{Tm})$ of fish gelatin film irradiated at different irradiation doses

\begin{tabular}{ccc}
\hline Radiation dose $(\mathrm{kGy})$ & $\mathrm{Tg}\left({ }^{\circ} \mathrm{C}\right)$ & $\mathrm{Tm}\left({ }^{\circ} \mathrm{C}\right)$ \\
\hline 0 & 59.23 & 214.02 \\
10 & 61.58 & 214.90 \\
20 & 64.12 & 213.18 \\
30 & 65.19 & 211.88 \\
40 & 66.55 & 212.16 \\
50 & 65.83 & 213.19 \\
\hline
\end{tabular}

Table 4. Characteristic infrared bands of peptide linkage

\begin{tabular}{ccl}
\hline Designation & Approxymate requency $\left(\mathrm{cm}^{-1}\right)$ & \multicolumn{1}{c}{ Description } \\
\hline Amide A & $3300-3270$ & NH stretching \\
Amide B & $3100-3030$ & NH stretching \\
Amide I & $1600-1690$ & $\mathrm{C}=\mathrm{O}$ stretching \\
Amide II & $1480-1575$ & $\mathrm{CN}$ stretching, NH bending \\
Amide III & $1229-1301$ & CN stretching, NH bending \\
Amide IV & $625-767$ & OCN bending \\
Amide V & $640-800$ & Out-of-plane NH bending \\
AmideVI & $573-606$ & Out-of-plane C=O bending \\
\hline
\end{tabular}

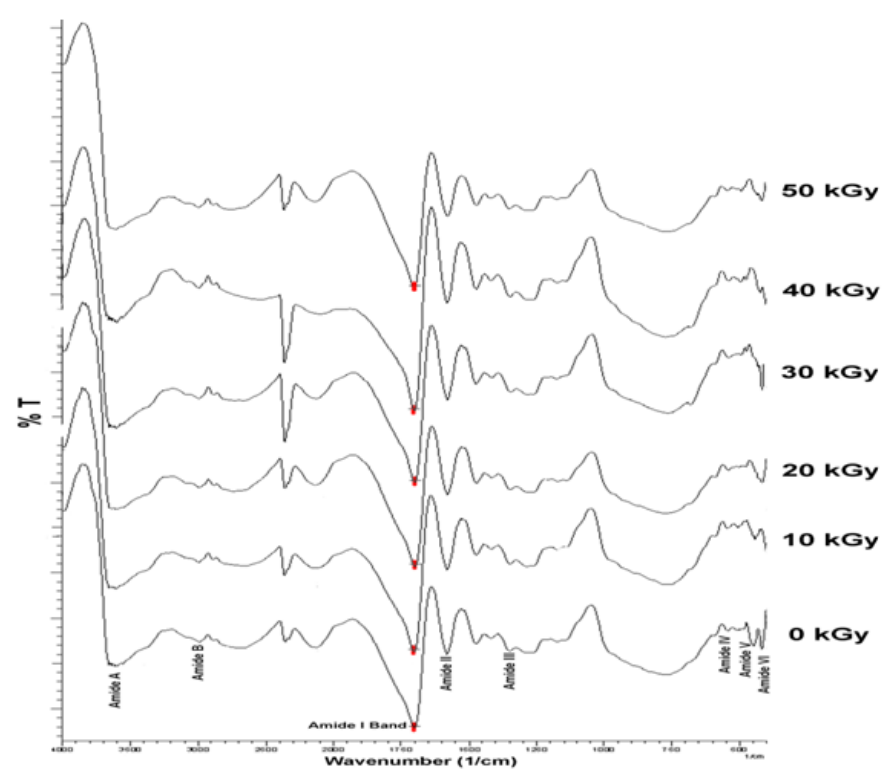

Fig 4. FTIR spectra of fish gelatin films irradiated at different irradiation doses

rearrangement of the triple helix into a random configuration [41-42].

Irradiated and control gelatin films showed glass transition temperature $(\mathrm{Tg})$ at around $60^{\circ} \mathrm{C}$ with broaden peak, as shown in Fig. 3. The Tg of gelatin film which lower than $150{ }^{\circ} \mathrm{C}$ indicated the gelatin films were not perfectly dehydrated [43]. But, moisture content of gelatin film is considered difficult to be controlled as gelatin film is easily dehydrated by water vapor in air. Increasing water content of gelatin film decreases the intensity, shift to lower temperature and broadens of the Tg peak because water has a plasticizer effect to gelatin film [44]. Sobral et al. [40] also reported that gelatin has glass transition temperature at $49{ }^{\circ} \mathrm{C}$ when they conditioned at $75 \%$ of relative humidity.

As shown in Table 3, Tg of irradiated film showed slight tendency to increase in relation to radiation doses. This result also indicated that gamma irradiation induced cross linking reaction in molecules of gelatin film. Plazek and Ngai [45] noted that one possible way to increase $\mathrm{Tg}$ is by increasing the cross link density. Reutner et al. [46] by using X-ray and calorimetry study proved that collagen-like structure of gelatin was rebuild by involving water as part of its formed crystals. Natively, water molecules absorbed into gelatin are found to be only partially crystallizable. The fraction of crystallizable water increases as increases of cross linking density. The evaporation of water and specifically of the crystallizable water giving rise to the $\mathrm{Tg}$ of gelatin film [46-48]. Several researches also reported that increased in $\mathrm{Tg}$ observed with the increase in cross linking of gelatin by chemical cross linker [48-50].

The Tg of irradiated film was spread between $211.88{ }^{\circ} \mathrm{C}$ and $214.90{ }^{\circ} \mathrm{C}$ with no correlation with radiation doses, as shown in Table 3 ,. This value was very close to the $\mathrm{Tm}$ of control film at $214.02{ }^{\circ} \mathrm{C}$. Previous studies generally found that cross linking did not change the melting point of gelatin film $[14,42,51]$.

\section{FTIR Characterization}

The FTIR spectra of gelatin extracted from Lates calcarifer scales using distilled water at $121{ }^{\circ} \mathrm{C}$ and pressure 1-1.5 atm for $20 \mathrm{~min}$ are shown in Fig. 4. It reveals that the FTIR spectra of gelatin films control $(0$ kGy) shows a typical spectrum for fish gelatin with three major peak regions marked as $1\left(3600-2700 \mathrm{~cm}^{-1}\right)$, 


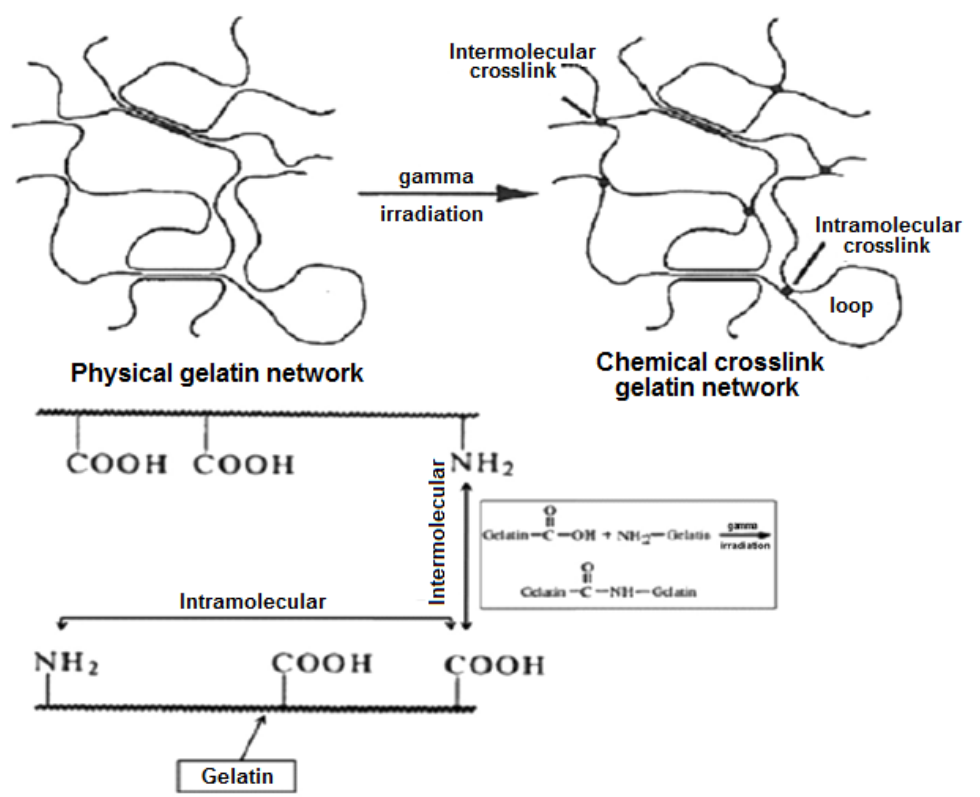

Fig 5. Illustrations of the effect of cross linking on gelatin network structure

$2\left(1900-900 \mathrm{~cm}^{-1}\right)$, and $3\left(900-400 \mathrm{~cm}^{-1}\right)$ related to vibration of the peptide linkage. The regions are assigned to the bonds: Amide A and B; Amide I, II, and III; and Amide IV, V, and VI [52-54]. The characteristic IR bands of gelatin are listed in Table 4.

The spectrum of irradiated gelatin film at doses up to $50 \mathrm{kGy}$ exhibited similar peaks with control, as shown in Fig. 4. Three major regions were showed similar shape and wave numbers at the peak. But it is observed that the intensity of transmittance at amide I band that was lower than control film.

The amide I are the most prominent vibrational bands of the protein backbone as it derived mainly (approximately $80 \%$ ) from the $\mathrm{C}=\mathrm{O}$ stretch vibrations of the peptide linkage [52,55-57]. Lower intensity of transmittance at amide I band of irradiated gelatin film indicated that gamma irradiation induced cross linking reaction in molecules of gelatin film through formation peptide linkage. As amide I band is the most sensitive spectral region to small variations in molecular geometry and hydrogen bonding patterns, lower intensity of transmittance may also related to formation secondary structure such as $\alpha$-helix and $\beta$-sheet of collagen-like gelatin molecular. Gelatin network structure after chemically cross linked was illustrated in Fig. 5 [58].

FTIR spectra of irradiated gelatin films indicated that carboxyl groups $(-\mathrm{COOH})$ and amine groups $\left(-\mathrm{NH}_{2}\right)$ in gelatin molecules are functional groups that involved in formation of peptide bond. Reaction between carboxyl and amine groups is induced by gamma radiation through indirect ionizing interaction. We hypothesized that radiolysis of water forms free radical that ionized carboxyl groups in gelatin molecules. The ionized carboxyl group is a very strong base which quickly forms corresponding amide when amine is present.

\section{CONCLUSION}

In summary, transparent gelatin film has been prepared from fisheries waste in the form of Lates calcarifer scales. Gamma irradiation at doses up to 50 kGy significantly $(p<0.05)$ improved the tensile strength and gel fraction of fish gelatin film without significant $(p, 0.05)$ change in Hunter color values. An increase of $\mathrm{Tg}$ of irradiated film related to radiation dose variation was also observed. FTIR spectra confirmed that improvement of mechanical and thermal properties was caused by cross-linking reaction that generated peptide linkage among gelatin molecules in irradiated film. We hypothesized the reaction mechanism involving radiolysis of water by gamma irradiation that generates free radicals which that caused ionization of carboxyl groups in gelatin molecule. The ionized carboxyl group is then reacted to amine group forms corresponding amide.

\section{ACKNOWLEDGEMENT}

Author gratefully acknowledge to colleagues at irradiation facilities PATIR-BATAN which has been providing the samples irradiation.

\section{REFERENCES}

1. Miller, K.S., and Krochta, J.M., 1997, Trends Food Sci. Technol., 8, 7, 228-237. 
2. Sobral, P.J.A., and Habitante, A.M.Q.B., 2001, Food Hydrocolloids, 15, 4-6, 377-382.

3. Park, J.W., Whiteside, W.S., and Cho, S.Y., 2008, LWT-Food Sci. Technol., 41, 4, 692-700.

4. Ikada, Y., and Tabata, Y., 2002, "Significance of Drug Delivery in Tissue Engineering" in Tissue Engineering and Biodegradable Equivalent: Scientific and Clinical Application. Eds. Lewandrowski, K.U., Wise, D.L., Trantolo, D.J., Gresser, J.D., Yaszemski, M.J., and Altobelli, D.E., Mercel-Decker Inc., New York, 154-194.

5. Matsuda, S., Iwata, H., Se, N., and Ikada, Y., 1999, J. Biomed. Mater. Res., 45, 1, 20-27.

6. Vaz, C.M., de Graaf, L.A., Reis, R.L., and Cunha, A.M., 2003, J. Mater. Sci. - Mater. Med., 14, 789796.

7. Kim, T.S., Bürklin, T., Schacher, B., Ratka-Krüger, B., Schaecken, M.T., Renggli, H.H., Fiehn, W., and Eickholz, P., 2002, J. Periodontol., 73, 11, 12851291.

8. Yue, I.C., Poff, J., Cortés, M.E., Sinisterra, R.D., Faris, C.B., Hildgen, P., Langer, R., and Shastri, 2004, Biomaterials, 25, 17, 3743-3750.

9. Djagny, K.B., Wang, Z., and Xu, S., 2001, Crit. Rev. Food Sci. Nutr., 41, 6, 481-492.

10. Pérez-Mateos, M., Montero, P., and Gómez-Guillén, M.C., 2009, Food Hydrocolloids, 23, 1, 53-61.

11. Duflo, S., Thibeault, S.L., Li, W., Shu, X.Z., and Prestwich, G.D., 2006, Tissue Eng., 12, 8, 21712180.

12. Miyoshi, M., Kawazoe, T., Igawa, H.H., Tabata, Y., Ikada, Y., and Suzuki, S., 2005, J. Biomater. Sci. Polym. Ed., 16, 7, 893-907.

13. Lee, S.B., Jeon, H.W., Lee, Y.W., Cho, S.K., and Lee, Y.M., 2003, Macromol. Res., 11, 5, 368-374.

14. Chiou, B-S., Avena-Bustillos, R.J., Bechtel, P.J., Jafri, H., Narayan, R., Imam, S.H., Glen, G.M., and Orts, W.J., 2008, Eur. Polym. J., 44, 11, 3748-3753.

15. Jongjareonrak, A., Benjakul, S., Visessanguan, W., Prodpran, T., and Tanaka, M., 2006, Food Hydrocolloids, 20, 4, 492-501.

16. Jongjareonrak, A., Benjakul, S., Visessanguan, W., and Tanaka, M., 2006, Eur. Food Res. Technol., 222, 229-235.

17. Jongjareonrak, A., Benjakul, S., Visessanguan, W., and Tanaka, M., 2006, Eur. Food Res. Technol., 222, 650-657.

18. Haug, I.J., Daget, K.I, and Smidsrød, O., 2004, Food Hydrocolloids, 18, 2, 203-213.

19. Garrison, W.M., 1987, Chem. Rev., 87, 2, 381-398.

20. Von Sonntag, C., 1995, "Trend of Research in Radiation Chemistry" in Advanced Radiation Chemistry Research: Current Status. IAEATECDOC-834, International Atomic energy Agency, Vienna, 11-41.
21. Fu, J., Shen, W., Bao, J., and Chen, Q., 2000, Radiat. Phys. Chem., 57, 345-348.

22. Gul-E-Noor, F., Khan, M.A., Ghoshal, S., Mazid, R.A., Chowdhury, A.M.S., and Khan, R.A., 2009, J. Macromol. Sci. Part A Pure. Appl. Chem., 46, 6, 615-624.

23. Jo, C., Kang, H., Lee, N.Y., Kwon, J.H., and Byun, M.W., 2005, Radiat. Phys. Chem., 72, 6, 745-750.

24. Hara, M., Koshimizu, N., Yoshida, M., Hauq, I.J., Ulset, A.S., and Christensen, B.E., 2010, J. Biomater. Sci., Polym. Ed., 21, 6, 877-892.

25. Bessho, M., Kojima, T., Okuda, T., and Hara, M., 2007, Bull. Chem. Soc. Jpn., 80, 5, 979-985.

26. Dhandayuthapani, B., Yoshida, Y., Maekawa, T., and Kumar, D.S., 2011, Int. J. Polym. Sci., 2011, $1-19$.

27. Simon, A., Grohens, Y., Vandanjon, L., Bourseau, P., Balnois, E., and Levesque, G, 2003, Macromol. Symp., 203, 1, 331-338.

28. Roussenova, M., Enrione, J., Diaz-Calderon, P., Taylor, A.J., Ubbink, J., and Alam, M.A., 2012, New J. Phys., 14, 3, 035016, 19 p.

29. Menegalli, F.C., Sobral, P.J., Roques, M.A., and Laurent, S., 1999, Drying Technol., 17, 7-8, 16971706.

30. Fraga, A.N., and Williams, R.J.J., 1985, Polymer, $26,1,113-118$.

31. Lee, M., Lee, S., and Song, K.B., 2005, Radiat. Phys. Chem., 72, 35-40.

32. Xu, W.H., Liu, B.Y., Yang, H.S., Liu, K.L., Jia, S.X., and Chen, F.S., 2012, Afr. J. Biotechnol., 22, 28, 7239-7246.

33. Machi, S., 1996, Radiat. Phys. Chem., 47, 3, 333336.

34. Lacroix, M., Le, T.C., Ouattara, B., Yu, H., Letendre, M., Sabato, S.F., Mateescu, M.A., and Patterson, G., 2002, Radiat. Phys. Chem., 63, 827-832.

35. Ressouany, M.M., Vachon, C., and Lacroix, M., 1998, J. Agric. Food Chem., 46, 4, 1618-1623.

36. Krajewski, A., Mazzocchi, M., Buldini, P.L., Ravaglioli, A., Tinti, A., Taddei, P., and Fragnano, C., 2005, J. Mol. Struct., 221, 744-747.

37. Carvalho, R.A., Sobral, P.J.A., Thomazine, M., Habitante, A.M.Q.B., Giménez, B., Goméz-Guillén, M.C., and Montero, P., 2008, Food Hydrocolloids, 22, 6, 1117-1123.

38. Goméz-Guillén, M.C., Pérez-Mateos, M., GomézEstaca, J., López-Caballero, E., Giménez, B., and Montero, P., 2009, Trends Food Sci. Technol., 20, 1, 3-16.

39. Langmaier, F., Kolomazník, K., Sukop, S., and Mládek, M., 1999, J. Soc. Leather Technol. Chem., 83, 4, 187-195. 
40. Sobral, P.J.A., Habitante, A.M.Q.B., and MonterreyQuintero, E.S., 2003, Braz. J. Food Technol., 6, 2, 327-331.

41. Bigi, A., Panzavolta, S., and Rubini, K., 2004, Biomaterials, 25, 25, 5675-5680.

42. Bigi, A., Cojazzi, G., Panzavolta, S., Rubini, K., and Roveri, N., 2001, Biomaterials, 22, 8, 763-768.

43. Yannas, I.V., 1972, J. Macromol. Sci., Polym. Rev., 7, 1, 49-106.

44. Pinhas, M.F., Blanshard, J.M.V., Derbyshire, W., and Mitchell, J.R., 1996, J. Therm. Anal. Calorim., 47, 5, 1499-1511.

45. Ngai, K.L., and Plazek, D.J., 2007, "Temperature Dependences of the Viscoelastic Response of Polymer Systems" in Physical Properties of Polymers Handbook, Eds. Mark, J.E., $2^{\text {nd }}$ ed., Springer, New York, 455-478.

46. Reutner, P., Luft, B., and Borchard, W., 1985, Colloid. Polym. Sci., 263, 519-529.

47. Apostolov, A.A., Fakirov, S., Vassileva, E., Patil, R.D., and Mark, J.E., 1998, J. Appl. Polym. Sci., 71, 3, 465-470.

48. Patil, R.D., Mark, J.E., Apostolov, A.A., Vassileva, E., and Fakirov, S., 2000, Eur. Polym. J., 36, 5, 1055-1061.
49. Akin, H., and Hasirci, N., 1995, J. Appl. Polym. Sci., 58, 1, 95-100.

50. Peña, C., de la Caba, K., Eceiza, A., Ruseckaite, R., and Mondragon, I., 2010, Bioresour. Technol., 101, 17, 6836-6842.

51. de Carvalho, R.A., and Grosso, C.R.F., 2004, Food Hydrocolloids, 18, 5, 717-726.

52. Kong, J., and Yu, S., 2007, Acta Biochim. Biophys. Sin., 39, 8, 549-559.

53. Pelton, J.T., and McLean, L.R., 2000, Anal. Biochem., 277, 2, 167-176.

54. Jacobsen, R.J., Brown, L.L., Hutson, T.B., Fink, D.J., and Veis, A., 1983, Science, 220, 4603, 1288-1290.

55. Krimm, S., and Bandekar, J., 1986, Adv. Protein Chem., 38, 181-364.

56. Susi, H., and Byler, D.M., 1986, Methods Enzymol., 130, 290-311.

57. Surewicz, W.K., and Manstsch, H.H., 1988, Biochim. Biophys. Acta., 952, 2, 115-130.

58. Kuijpers, A.J., Engbers, G.H.M., Feijen, J., de Demeester, J., Kriigsyeld, J., Zaat, S.A.J., and Dankert, J., 1999, Macromolecules, 32, 3325-333. 